\title{
A study of Phytophthora spp. in declining highbush blueberry in Germany reveals that $P$. cinnamomi can thrive under Central European outdoor conditions
}

\author{
Jan Nechwatal ${ }^{1} \cdot$ Thomas Jung $^{2,3}$ \\ Received: 15 December 2020 / Accepted: 12 February 2021 / Published online: 9 March 2021 \\ (c) The Author(s) 2021
}

\begin{abstract}
Phytophthora cinnamomi and P. cactorum were detected in soil samples from a Vaccinium corymbosum stand in southern Germany. Both species were virulent in an underbark inoculation assay and have not been reported from highbush blueberry in Germany before. While P. cactorum is a widely distributed species in nurseries and (semi)natural habitats like forests, field reports of P. cinnamomi in Germany are rare due to its sensitivity to frost. Its occurrence in an outdoor blueberry stand indicates its potential to survive Central European winter periods that tend to be increasingly mild. Phytophthora cinnamomi was also found in the substrate of young V. corymbosum nursery plants, suggesting a high degree of contamination in commercial blueberry production and demonstrating the risk of spreading exotic invasive plant pathogens via planting of infested nursery stock.
\end{abstract}

Keywords Blueberry disease $\cdot$ Global warming $\cdot$ Nursery $\cdot$ Phytophthora cactorum $\cdot$ Phytophthora cinnamomi $\cdot$ Vaccinium corymbosum

\section{Introduction}

Northern highbush blueberry (Vaccinium corymbosum, Ericaceae) is increasingly cultivated in Germany due to a steadily growing customer demand for its fruit, both for supply via retail markets and for on-farm "pick-your-own" facilities. Blueberry acreage in Germany in 2018 was more than 3000 ha, constituting a more than $60 \%$ increase compared to 2012 (Anonymus 2019).

In summer 2020, a severe decline was observed in an outdoor northern highbush blueberry container stand in Lower Bavaria, southern Germany in a "pick-your-own"

Jan Nechwatal

jan.nechwatal@1fl.bayern.de

1 Bavarian State Research Center for Agriculture, Institute for Plant Protection, Lange Point 10, 85354 Freising, Germany

2 Phytophthora Research Centre, Department of Forest Protection and Wildlife Management, Faculty of Forestry and Wood Technology, Mendel University, Zemědělská 3, 61300 Brno, Czech Republic

3 Phytophthora Research and Consultancy, Am Rain 9, 83131 Nussdorf, Germany berry farm. By the end of June, approximately $30 \%$ of a total of 1,400 plants were dead or heavily affected, showing severe signs of disease, i.e. wilting and yellowing of foliage, dieback of twigs and branches (Figs. 1 and 2). In addition, root systems were severely reduced, so that affected plants could easily be pulled out the substrate. Remaining root balls were small, dark in colour and with a high proportion of damaged roots. The blueberry stand was established in 2018 with young container plants purchased from a large wholesale nursery in Northern Germany transplanted singly into large plastic containers $(90 \mathrm{~L})$, in a mixture of peat and sawdust, and covered with a layer of wood chips. The containers were arranged approximately $40 \mathrm{~cm}$ apart, in rows spaced about $3 \mathrm{~m}$ (see Fig. 1). Their bottoms were perforated for drainage. Plants were watered from a nearby natural spring/ pond and fertilised as recommended. Initially, two varieties were grown on the site: 'Duke' and 'Bluecrop'. First visible symptoms began to develop already in 2019 in 'Duke', and several plants were replaced by newly purchased ones of variety 'Reka'. However, by summer 2020 , all three varieties were equally affected by the disease.

Vaccinium corymbosum is a well-known host plant of several Phytophthora species, in particular the notorious $P$. cinnamomi, causing severe disease and declines all over the 
Fig. 1 General view of the affected Northern highbush blueberry stand, with most of the plants in the foreground rows severely affected, dead, or already removed

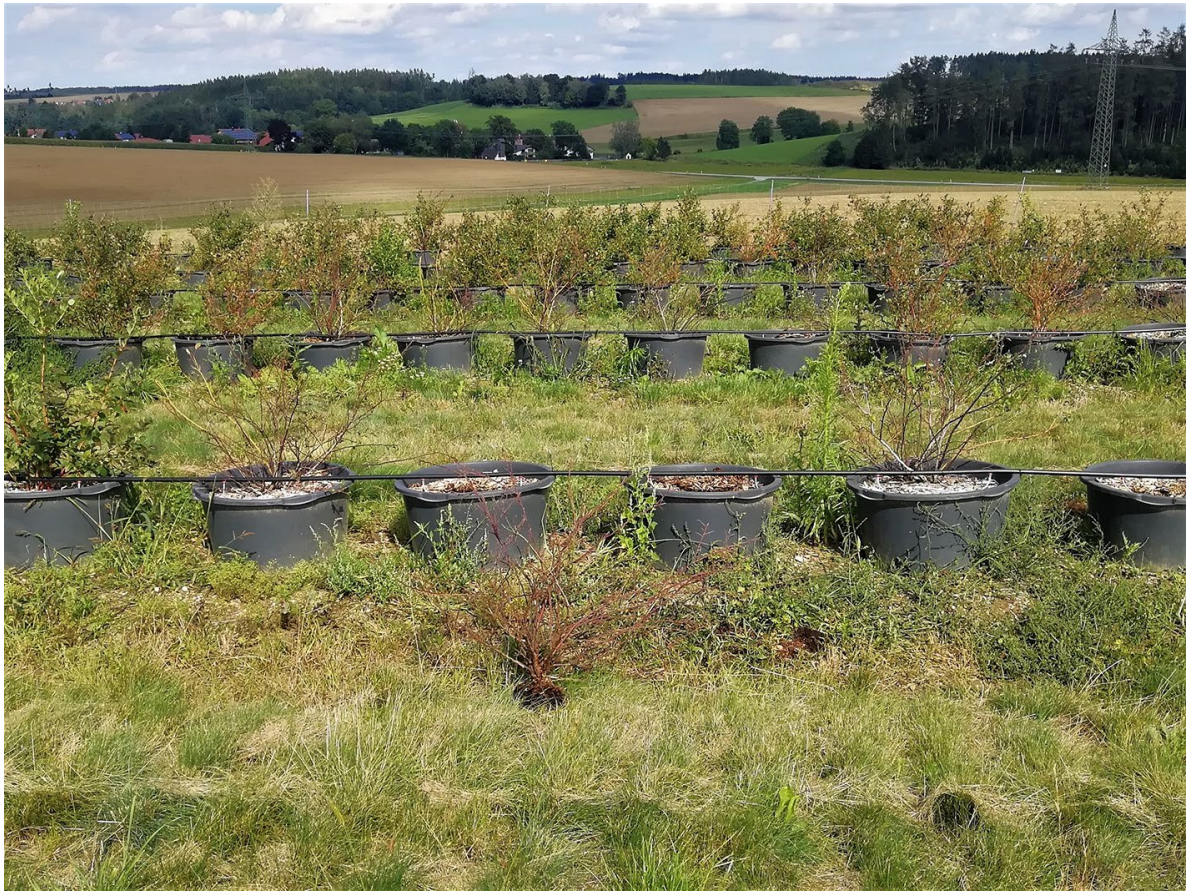

world (Sterne 1982; Tamietti 2003; Bryla et al. 2008; Larach et al. 2009; Orlikowski et al. 2015; Lan et al. 2016; Huarhua et al. 2018). Therefore, an investigation was initiated into the potential involvement of Phytophthora spp. in this particular disease outbreak.

\section{Materials and methods}

\section{Sampling and isolation methods}

Three mixed samples (approx. 1 L) of substrate randomly taken from the remaining root balls of a selection of affected plants were taken during summer and autumn 2020. A differentiation according to variety could not be made, as the declining plants could not be readily discriminated. Soil samples were brought to the laboratory and subjected to a baiting test using young oak (Quercus robur) leaves or blue lupine (Lupinus angustifolius) seedlings as baits (Erwin and Ribeiro 1996; Jung et al. 1996). After 4-14 days, baits showing signs of infection were scored for sporangia under a light microscope at $\times 80$ magnification. Small segments from necrotic areas with sporangia typical for the genus were plated onto V8 juice agar (V8A, Jung and Nechwatal 2008) after being washed, dipped in $80 \%$ ethanol and carefully blotted dry. Hyphae indicative of Phytophthora spp. developing after $24 \mathrm{~h}-48 \mathrm{~h}$ were transferred to fresh V8A plates and subcultured if needed for further purification from bacteria and Pythium spp., and for identification.

\section{Morphological and molecular species identification}

Phytophthora isolates obtained from the substrate samples were examined microscopically for the production and dimensions of chlamydospores, sporangia and gametangia. Sporangia formation was induced by flooding $1 \mathrm{~cm}$ squares cut from actively growing V8A cultures for $24 \mathrm{~h}-48 \mathrm{~h}$ in nonsterile soil filtrate (Jung et al. 1996). For each isolate each 40 sporangia, oogonia and oospores were measured if present. Selfsterile isolates were paired with A1 and A2 mating type strains of $P$. cinnamomi to identify whether they are sterile or heterothallic and to which mating type heterothallic isolates belong (Jung et al. 2020). Characteristic features and sizes of morphological structures were compared with descriptions and dimensions reported in the literature (Erwin and Ribeiro 1996). Molecular identification was based on the sequences of the internal transcribed spacer regions (ITS) 1 and ITS 2, and the 5.8S rRNA gene of the nuclear rDNA gene cluster and the cytochrome oxidase subunit 1 gene, as described elsewhere, using the primers ITS 6 and ITS 4 or COXF4N and COXR4N (Cooke and Duncan 1997; Kroon et al. 2004). Sequences were compared to those deposited in the GenBank database at NCBI using Blast searches (https ://www.ncbi.nlm.nih.gov/BLAST). 


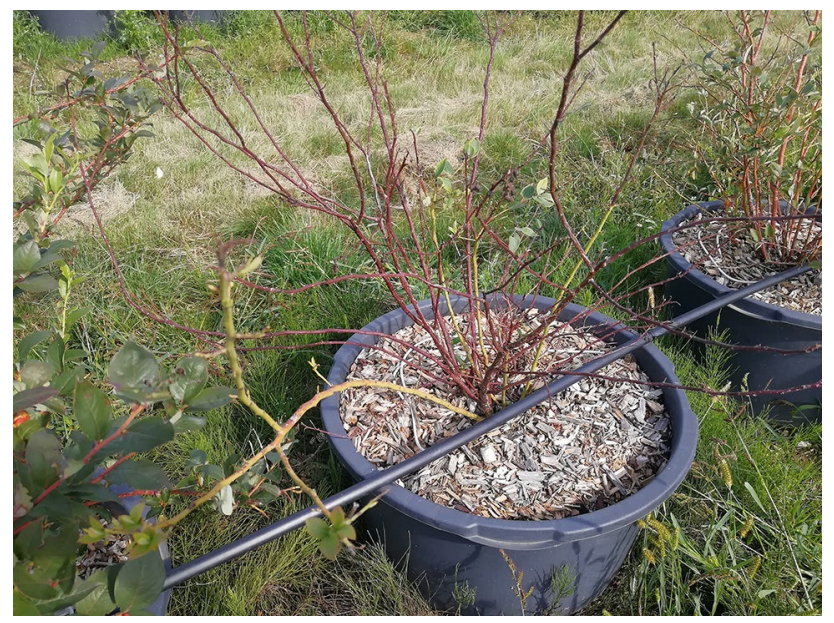

Fig. 2 Severely damaged Northern highbush blueberry container plant in the affected stand

\section{Pathogenicity trial}

One-year-old green $V$. corymbosum (variety 'Reka') twigs (approx. $3 \mathrm{~mm}-5 \mathrm{~mm}$ in diameter) without obvious signs of disease were collected from commercial plants purchased from a garden centre for an underbark inoculation assay with Phytophthora isolates, as reported earlier (Jung and Nechwatal 2008). Eight twigs per isolate were cut to about $15 \mathrm{~cm}$ length and surface disinfected by wiping with $80 \%$ ethanol. After inoculation with agar discs of the Phytophthora isolates or as a control, with non-inoculated V8A discs, twigs were incubated at $24{ }^{\circ} \mathrm{C}$ for one week.

For a planned soil infestation assay, young Vaccinium corymbosum plants (variety 'Reka') were purchased from a large commercial nursery in northern Germany. Upon arrival, a soil sample pooled from the root balls of all ten plants was collected and subjected to a bait test as described above. The test revealed a heavy Phytophthora infestation of the plants (see below). Due to the severe risk of contamination expected for any plants purchased from commercial suppliers, a soil infestation test could not be performed during the present study.

\section{Results}

In the baiting tests, Phytophthora isolates were obtained from two of the three soil samples taken in the "pick-yourown" blueberry stand, while from the third sample no Phytophthora was isolated. The two isolates (one species from each sample) were tentatively identified as $P$. cinnamomi (isolate AT0) and P. cactorum (isolate AT1) based on characteristic morphological features of their reproductive structures and hyphae.

Phytophthora cinnamomi had ovoid, non-papillate, but apically thickened sporangia, on average $48 \times 34 \mu \mathrm{m}$ (30-70 $\times 24-44 \mu \mathrm{m})$ in size, with a mean length/breadth ratio (L/B) of 1.39, internal, sometimes nested proliferation, and conspicuously coralloid, swollen and irregular hyphae, clusters of spherical hyphal swellings and thin-walled chlamydospores of highly variable size. Oogonia and oospores were not observed in single culture, but they were produced in the pairing with an A1 mating type tester strain of $P$. cinnamomi, revealing that isolate AT0 belonged to mating type A2. Phytophthora cactorum was characterised by the production of oogonia and slightly aplerotic oospores (typically $25 \mu \mathrm{m}-32 \mu \mathrm{m}$ and $23 \mu \mathrm{m}-30 \mu \mathrm{m}$ in diameter, respectively), monoclinous, paragynous antheridia and broad ovoid sporangia, on average $45 \times 37 \mu \mathrm{m}(38-50 \times 30-42 \mu \mathrm{m}$, mean L/B 1.21 ) with a conspicuous papilla (ca. $5 \mu \mathrm{m}$ long). Sporangia were caducous with a very short pedicel $(<4 \mu \mathrm{m})$ (Fig. 3$)$.

Remarkably, a substrate sample taken from young $V$. corymbosum plants originally purchased for a planned soil infestation test also readily revealed $P$. cinnamomi, as suggested by the isolates' typical morphological features (isolate B1).

The morphological identification of all isolates was confirmed by ITS and cox 1 sequence data analysis. Sequence identity was $100 \%$ to a selection of GenBank entries of the respective species. Sequences were deposited in the GenBank database under the accession numbers MW287138 (AT0), MW242712 (AT1) and MW242744 (B1) for ITS and MW503943 (AT0), MW503945 (AT1) and MW503944 (B1) for cox 1 .

Both $P$. cinnamomi and $P$. cactorum proved to be highly aggressive to $V$. corymbosum 'Reka' in the twig underbark inoculation assay. First visible symptoms on twigs appeared less than $24 \mathrm{~h}$ after inoculation with both Phytophthora species. After one week, both species had produced large necroses with average lengths of $3.9 \mathrm{~cm}$ in length for $P$. cinnamomi and $3.4 \mathrm{~cm}$ for $P$. cactorum. Variation in lesion length caused by both Phytophthora species was high, with lengths ranging from $1-6 \mathrm{~cm}$. Reisolations from infected twigs readily confirmed the species originally inoculated. Controls remained healthy, without any visual symptom development.

\section{Discussion}

Diseases of blueberry, in particular V. corymbosum, caused by $P$. cinnamomi have long been reported from all over the world. First reports from the U.S. date back to the 1970s (Sterne 1982), and the disease has since been reported from 

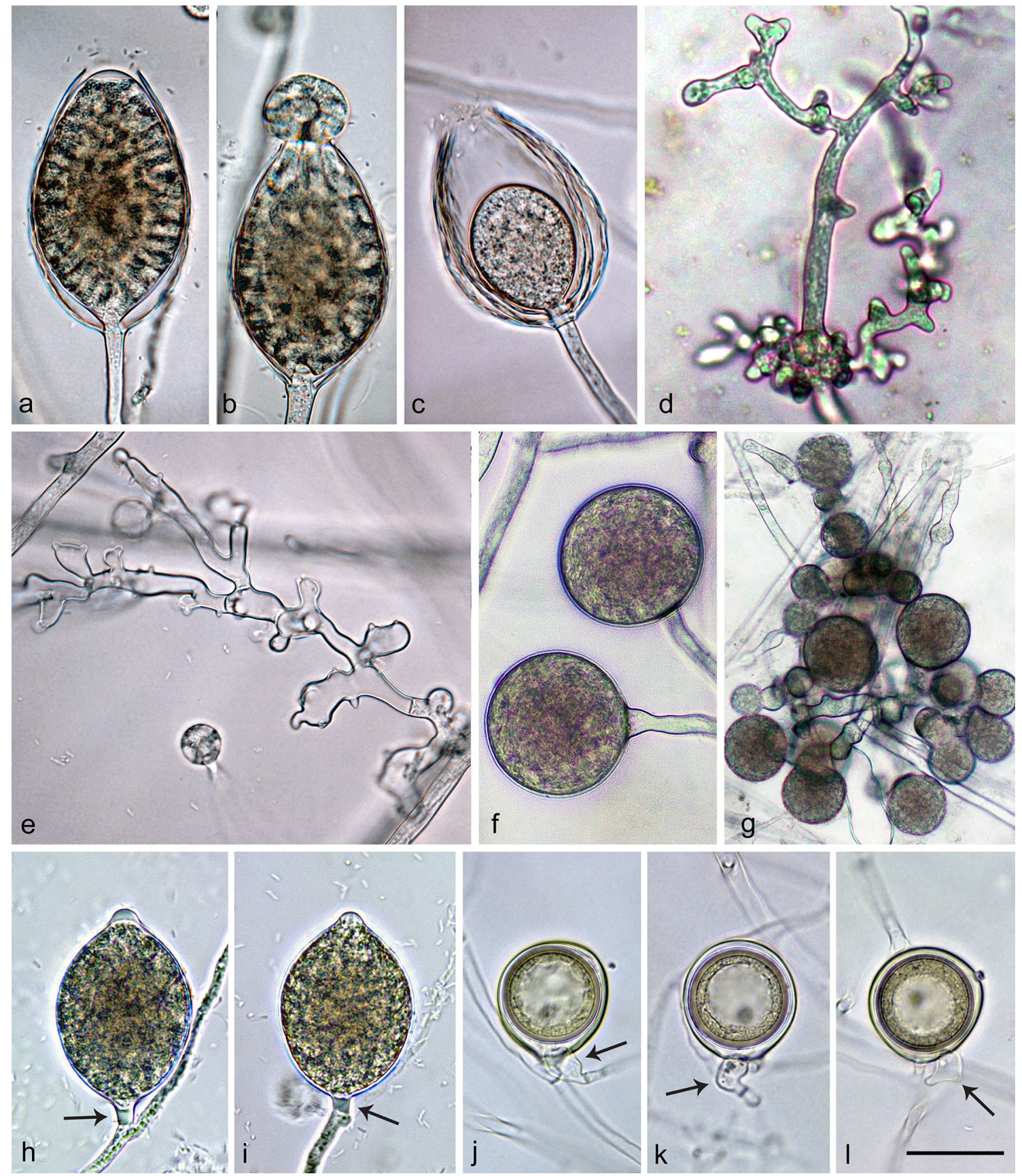

Fig. 3 Morphological structures of Phytophthora cinnamomi and $P$. cactorum; a-g. morphological structures of $P$. cinnamomi isolate AT0: a ellipsoid non-papillate sporangium with nested proliferation inside an empty sporangium shortly before zoospore release; b elongated-ovoid sporangium releasing zoospores; c sporangium showing multiple nested proliferations; d, e typical coralloid lateral hyphae (after cytoplasm retraction in e.); $\mathbf{f}$ thin-walled chlamydo-

South America, Asia and Europe (Tamietti 2003; Larach et al. 2009; Orlikowski et al. 2015; Lan et al. 2016; Huarhua et al. 2018). While in 2010 P. $\times$ cambivora was isolated from a young plantation of $V$. ovata in Germany (Jung et al. 2016), so far no incidence of Phytophthora spp. in general spores; g cluster of irregular hyphal swellings and chlamydospores; $\mathbf{h}-\mathbf{l}$ morphological structures of $P$. cactorum isolate AT1: $\mathbf{h}-\mathbf{i}$. ovoid papillate sporangia with typical very short pedicels (arrows); $\mathbf{j}-\mathbf{l}$. globose to subglobose, slightly aplerotic oogonia formed in solid V8A, with thick-walled oospores and paragynous antheridia (arrows); scale bar $=25 \mu \mathrm{m}(\mathrm{a}-\mathrm{f}$ and $\mathrm{h}-\mathrm{l})$; scale bar $=50 \mu \mathrm{m}(\mathrm{g})$

and $P$. cinnamomi in particular on V. corymbosum has been reported from Germany.

In the present study, $P$. cinnamomi and $P$. cactorum were isolated from the rhizosphere of declining plants of $V$. corymbosum in a "pick-your-own" berry farm in Southern 
Germany suffering from symptoms like wilting and yellowing of foliage, dieback of twigs and a severe reduction of the root system. Phytophthora cinnamomi was also recovered from $V$. corymbosum plants purchased from a commercial nursery in Northern Germany. Both P. cinnamomi and $P$. cactorum proved to be aggressive to $V$. corymbosum in an underbark inoculation assay.

Phytophthora cinnamomi is undoubtedly the most notorious globalised plant pathogen with a confirmed host range of almost 5,000 plant species (Erwin and Ribeiro 1996; Hardham and Blackman 2018). The origin of $P$. cinnamomi lies in Southeast Asia where both mating types A1 and A2 cooccur in a balanced ratio (Ko et al. 1978; Jung et al. 2020). The global epidemic is driven by two clonally spreading genotypes of the A2 mating type (Engelbrecht et al. 2017; Socorro-Serrano et al. 2019). Based on old reports of typical ink disease symptoms of Castanea sativa in Portugal, $P$. cinnamomi is suspected to have been introduced to Southern Europe in the early 1800s (Crandall et al. 1945). Mating type A2, in particular, is generally considered to be more adapted to warmer regions, suffering from, or unable to survive, severe winter frost (Erwin and Ribeiro 1996; Jung et al. 2020). Accordingly, only few records of this pathogen to occur in Germany exist, mostly from nurseries (Jung et al. 2016). Zinkernagel and Kröber (1978) already suggested that $P$. cinnamomi can tolerate winter temperatures in Germany in climatically favoured areas. However, with a changing climate and rising temperatures on a global scale, a range expansion of the pathogen to regions previously too cold for its survival can be expected (Brasier and Scott 1994; Bergot et al. 2004; Burgess et al. 2017). Indeed, there are a number of recent reports indicating that $P$. cinnamomi will increasingly be able to thrive in Central Europe under outdoor conditions. Recently, P. cinnamomi was detected in $C$. sativa stands in SW Germany, a region known for its mild climate and comparably high mean winter temperatures, constituting its first detection in a forest stand in Germany. Remarkably, the affected trees originated from natural regeneration and had no direct connection to a nursery (Peters et al. 2019). In 2015 and 2017, P. cinnamomi was isolated from bleeding stem cankers of mature Juglans regia in Austria and Araucaria araucana in Germany, respectively (T. Jung, T. Cech and T. Corcobado, unpublished results). In Poland, P. cinnamomi was found causing a decline of a Quercus robur stand (Oszako and Orlikowski 2005). The present report provides additional evidence that this pathogen is increasingly able to survive Central European winter, in particular when severe frost events are lacking, causing severe disease symptoms in the field. The affected blueberry stand in Lower Bavaria was established two years before the pathogen's detection. Assuming that P. cinnamomi was already present in the nursery plants at the time of planting, the pathogen had already survived two winter periods in a region not known for having mild winters. Mean winter minimum temperatures in the region in 2018-2020 have been considerably higher than the long-term average (1971-2000) (www.wetter-by.de).

Phytophthora cactorum is another species frequently detected in nurseries all over Europe. It is well established in Central Europe and has been found associated with many different woody hosts, both in nurseries and in forest stands (Jung et al. 2016). An association with highbush blueberry has not been reported from anywhere in the world yet. However, according to the results of the twig inoculation test and the disease incidence in the stand, P. cactorum appears to be similarly aggressive as $P$. cinnamomi. However, while the virulence of $P$. cinnamomi to highbush blueberry is undoubted and disease aetiology well understood, for $P$. cactorum a soil infestation test is needed to finally confirm its aggressiveness and pathological importance.

Together with the well-documented susceptibility of $V$. corymbosum to $P$. cinnamomi and its frequent association with several other Phytophthora spp. in European nurseries (Jung et al. 2016), the results of the present study suggest that $V$. corymbosum (just like Vaccinium spp. in general and other members of the Ericaceae) is susceptible to a range of Phytophthora species, while at the same time Vaccinium nursery stock might be heavily infested with Phytophthora spp. The latter was impressively demonstrated by the isolation of $P$. cinnamomi from young $V$. corymbosum plants purchased during the present study from a commercial nursery. In accordance with results from a Europe-wide study on ubiquitous Phytophthora infestations of nursery stock, a widespread contamination of $V$. corymbosum nursery plants and beds with Phytophthora spp. can be assumed. Therefore, newly established blueberry farms are in danger of experiencing severe disease problems when using these plants. Interestingly, in that study, over all nursery stands high proportions of the $>1,800$ Phytophthora isolates belonged to either P. cinnamomi or $P$. cactorum (Jung et al. 2016).

Although infestation of the affected "pick-your-own" berry stand via re-circulated irrigation water originating from a natural spring, substrates or other sources, such as strawberry plants growing nearby, cannot be excluded, it seems likely that the pathway of both Phytophthora pathogens into the stand was via infested nursery stock. Being soilborne primary pathogens, $P$. cactorum and P. cinnamomi do not thrive in aquatic ecosystems. In numerous surveys in various countries, $P$. cinnamomi could not be isolated from streams and waterbodies even when it was commonly found in the soils surrounding the waterbodies (Hüberli et al. 2013; Shrestha et al. 2013; Jung et al. 2020). With a changing climate and, in particular, increasingly milder winter temperatures, the risk of nursery-transmitted, invasive, exotic Phytophthora species to become established in outdoor agricultural, horticultural or silvicultural stands in 
temperate zones is significantly increasing (Brasier and Scott 1994; Bergot et al. 2004; Jung et al. 2016). Perhaps the most notorious candidate species is the (sub) tropical and Mediterranean pathogen $P$. cinnamomi which currently appears to be on its way to become a serious threat to Central European fields, gardens and forests.

Funding Open Access funding enabled and organized by Projekt DEAL.

\section{Compliance with ethical standards}

Conflict of interest All authors declare that they have no conflict of interest.

Open Access This article is licensed under a Creative Commons Attribution 4.0 International License, which permits use, sharing, adaptation, distribution and reproduction in any medium or format, as long as you give appropriate credit to the original author(s) and the source, provide a link to the Creative Commons licence, and indicate if changes were made. The images or other third party material in this article are included in the article's Creative Commons licence, unless indicated otherwise in a credit line to the material. If material is not included in the article's Creative Commons licence and your intended use is not permitted by statutory regulation or exceeds the permitted use, you will need to obtain permission directly from the copyright holder. To view a copy of this licence, visit http://creativecommons.org/licenses/by/4.0/.

\section{References}

Anonymus (2019) Heidelbeeranbau deutlich gestiegen („Blueberry cultivation markedly increased“). Proplanta, das Informationszentrum für die Landwirtschaft. https://www.proplanta.de/agrar -nachrichten/pflanze/heidelbeeranbau-deutlich-gestiegen_artic le1550302714.html. Accessed 15 December 2020

Bergot M, Cloppet E, Pérarnaud V, Déqué M, Marçais B, DesprezLoustau M-L (2004) Simulation of potential range expansion of oak disease caused by Phytophthora cinnamomi under climate change. Glob Chang Biol 10:1539-1552

Brasier CM, Scott JK (1994) European oak declines and global warming: a theoretical assessment with special reference to the activity of Phytophthora cinnamomi. EPPO Bull 24:221-232

Bryla DR, Linderman RG, Yan WQ (2008) Incidence of Phytophthora and Pythium infection and the relation to cultural conditions in commercial blueberry fields. HortScience 43:260-263

Burgess TI, Scott JK, Mcdougall KL, Stukely MJC, Crane C, Dunstan WA, Brigg F, Andjic V, White D, Rudman T, Arentz F, Ota N, Hardy GEStJ, (2017) Current and projected global distribution of Phytophthora cinnamomi, one of the world's worst plant pathogens. Glob Chang Biol 23:1661-1674

Cooke DEL, Duncan JM (1997) Phylogenetic analysis of Phytophthora species based on ITS1 and ITS2 sequences of the ribosomal RNA gene repeat. Mycol Res 101:667-677

Crandall BS, Gravatt GF, Ryan MM (1945) Root disease of Castanea species and some coniferous and broadleaf nursery stocks, caused by Phytophthora cinnamomi. Phytopathology 35:162-180

Engelbrecht J, Duong TA, Berg NVD (2017) New microsatellite markers for population studies of Phytophthora cinnamomi, an important global pathogen. Sci Rep 7:17631
Erwin DC, Ribeiro OK (1996) Phytophthora diseases worldwide. APS Press, St. Paul

Hardham AR, Blackman LM (2018) Phytophthora cinnamomi. Mol Plant Pathol 19:260-285

Huarhua M, Flores J, Acuña R, Apaza W (2018) Morphological and molecular identification of Phytophthora cinnamomi Rands as causal agent of crown and root rot in blueberry (Vaccinium corymbosum) in Peru. Peruvian J Agron 2:14-21

Hüberli D, Hardy GESTJ, White D, Williams N, Burgess TI (2013) Fishing for Phytophthora from Western Australia's waterways: a distribution and diversity survey. Australas Plant Path 42:251-260

Jung T, Nechwatal J (2008) Phytophthora gallica sp. nov., a new species from rhizosphere soil of declining oak and reed stands in France and Germany. Mycol Res 112:1195-1205

Jung T, Blaschke H, Neumann P (1996) Isolation, identification and pathogenicity of Phytophthora species from declining oak stands. Eur J For Pathol 26:253-272

Jung T, Orlikowski L, Henricot B, Abad-Campos P et al (2016) Widespread Phytophthora infestations in European nurseries put forest, semi-natural and horticultural ecosystems at high risk of Phytophthora diseases. For Pathol 46:134-163

Jung T, Scanu B, Brasier CM, Webber J, Milenković I, Corcobado T, Tomšovský M, Pánek M, Bakonyi J, Maia C, Bačová A, Raco M, Rees H, Pérez-Sierra A, Horta Jung M (2020) A survey in natural forest ecosystems of Vietnam reveals high diversity of both new and described Phytophthora taxa including P. ramorum. Forests 11:93

Ko WH, Chang HS, Su HJ (1978) Isolates from Phytophthora cinnamomi from Taiwan as evidence for an Asian origin of the species. Trans Br Mycol Soc 71:496-499

Kroon LPNM, Bakker FT, van den Bosch GBM, Bonants PJM, Fliera WG (2004) Phylogenetic analysis of Phytophthora species based on mitochondrial and nuclear DNA sequences. Fungal Genet Biol 41:766-782

Lan CZ, Ruan HC, Yao JA (2016) First report of Phytophthora cinnamomi causing root and stem rot of blueberry (Vaccinium corymbosum) in China. Plant Dis 100:2537

Larach A, Besoain X, Salgado E (2009) Crown and root rot of highbush blueberry caused by Phytophthora cinnamomi and P. citrophthora and cultivar sensitivity. Cien Inv Agr 36:433-442

Orlikowski L, Ptaszek M, Meszka B (2015) Phytophthora cinnamomi - new pathogen of high blueberry in Poland. Prog Plant Prot 55:472-477

Oszako T, Orlikowski LB (2005) The first data on the occurrence of Phytophthora cinnamomi on English oak in Poland. Sylwan 149:47-53

Peters FS, Wunderlich F, Metzler B (2019) First report of Phytophthora cinnamomi in forest stands in Germany. Forest Pathol 49:e12485

Shrestha SK, Zhou Y, Lamour K (2013) Oomycetes baited from streams in Tennessee 2010-2012. Mycologia 105:1516-1523

Socorro Serrano M, Osmundson T, Almaraz-Sanchez A, Croucher PJ, Swiecki T, Alvarado-Rosales D, Garbelotto M (2019) A microsatellite analysis identifies global pathways of movement of Phytophthora cinnamomi and the likely sources of wildland infestations in California and Mexico. Phytopathology 109:1577-1593

Sterne RE (1982) Phytophthora root rot of blueberry in Arkansas. Plant Dis 66:604-605

Tamietti G (2003) First report of Phytophthora cinnamomi on highbush blueberry in Italy. Plant Dis 87:451

Zinkernagel V, Kröber H (1978) Phytophthora cinnamomi Rands als Erreger einer Triebfäule an Gaultheria procumbens L. Nachrichtenbl Deut Pflanzenschutzd 30:181-183

Publisher's Note Springer Nature remains neutral with regard to jurisdictional claims in published maps and institutional affiliations. 